\title{
INFLUENCE OF SPATIAL RESOLUTION IN MODELING THE DISPERSION OF VOLCANIC ASH IN ECUADOR
}

\author{
RENÉ PARRA \\ Instituto de Simulación Computacional, Universidad San Francisco de Quito, Ecuador
}

\begin{abstract}
Volcanic ash produces air pollution and other impacts. Regions potentially affected require information about the possible ash dispersion trajectories and affected zones by ash fallout. In the last 19 years, five volcanoes in Ecuador have produced moderate to large explosive eruptions. Information about the volcanic ash dispersion in forecasting time is a priority in Ecuador. Eulerian models can provide results with high spatial and temporal resolutions. However, they need to solve huge amounts of equations, demanding plenty of computational resources when using high spatial resolutions. It is necessary to define a pragmatic spatial resolution, suitable to compute volcanic ash dispersion, both in forecasting time and with enough accuracy. For this purpose, we simulated the meteorology over Ecuador, using the Weather Research and Forecasting (WRF3.7.1) model with spatial resolutions of $36 \mathrm{~km}, 12 \mathrm{~km}$, $4 \mathrm{~km}$, and $1 \mathrm{~km}$. Meteorological outputs were used into the FALL3DV7.1.4 model to simulate ash dispersion from four eruptions (Tungurahua volcano: 16 December 2012, 14 July 2013 and 1 February 2014; Cotopaxi volcano: 14 August 2015). We compared modeled ash fallout results with records from ash meters around these volcanoes. The coarser resolutions of $36 \mathrm{~km}$ and $12 \mathrm{~km}$, provided low modeling performances, with values of the linear correlation coefficient $\left(\mathrm{R}^{2}\right)$ between 0.00 to 0.79 ; and 0.28 to 0.46 respectively. Modeling with $4 \mathrm{~km}$ improved the performance, reaching values of $\mathrm{R}^{2}$ between 0.56 to 0.98 . The resolution of $1 \mathrm{~km}$ got the best performance, with $\mathrm{R}^{2}$ between 0.70 to 1.00 . Nevertheless, when working with $1 \mathrm{~km}$, it demanded about 20 computational times in comparison with $4 \mathrm{~km}$. These results suggest that for the Ecuadorian case, the resolution of $4 \mathrm{~km}$ is a good compromise for generating volcanic ash dispersion in forecasting time, with proper modeling performance.
\end{abstract}

Keywords: WRF, FALL3D, forecasting time, Cotopaxi, Tungurahua.

\section{INTRODUCTION}

Volcanic ash produces air pollution and other environmental impacts [1], [2]. Regions potentially affected require information about the possible ash dispersion trajectories and affected zones by ash fallout.

Prevailing winds at different altitudes disperse volcanic ash. So, the meteorological component of Atmospheric Transport Models (ATMs) (e.g. [3], [4]), provides key information when modeling the dispersion of volcanic ash. ATMs also require volcanological inputs, the Eruption Source Parameters (ESP) [5], which include information about particle grain size distribution, and the characterization of the source term (i.e., plume height, eruption duration, mass eruption rate, and vertical distribution of mass along the eruptive column).

In the last 19 years, five volcanoes in Ecuador produced moderate to large explosive eruptions with significant ash plumes (Pichincha 1999-2001, Sangay permanent, Tungurahua 1999 to present, El Reventador 2002 to present, Cotopaxi 2015). Hence, information in forecasting time about the volcanic ash dispersion is a priority in Ecuador.

Eulerian ATMs describe the behavior of the atmosphere into domains composed of threedimensional arrays of fixed grid cells. For mesoscale studies, ATMs use grid cells with resolutions of few $\mathrm{km}$, providing results with high spatial and temporal resolutions. However, they solve huge amounts of equations, demanding plenty of computational resources. The need for high-resolution simulations (up to $1 \mathrm{~km}$ ) comes from the better representation of small scale processes of dispersion processes [6]. It is necessary to define a pragmatic spatial 
resolution, suitable to compute volcanic ash dispersion, both in forecasting time and with proper accuracy.

Tungurahua (lon. $78.446^{\circ} \mathrm{W}$, lat. $1.468^{\circ} \mathrm{S} ; 5023 \mathrm{~m}$ asl), located in the Ecuadorian Andes (Fig. 1), began its activity in October 1999. Since then, ash fallout was the most frequent volcanic hazard [7], [8]. Based on field and modeling studies, ESP were proposed for forecasting ash dispersion due to Vulcanian eruptions at this volcano [4].
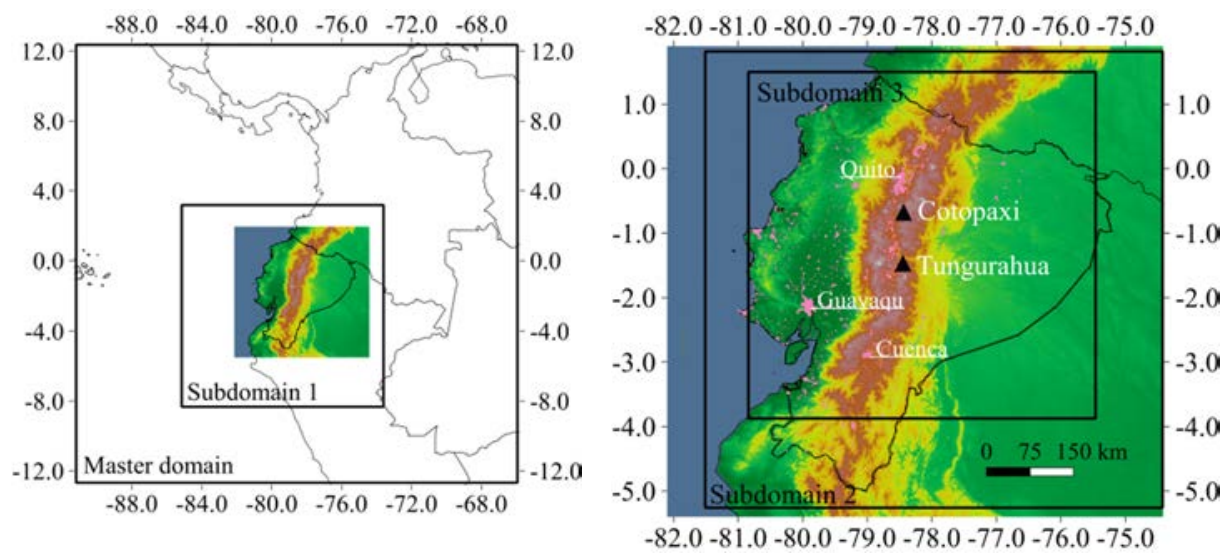

Figure 1: Location of Cotopaxi and Tungurahua volcanoes. Domains for modeling: Master domain $(80 \times 80$ cells, $36 \times 36 \mathrm{~km})$, subdomain $1(109 \times 109$ cells, $12 \times 12 \mathrm{~km})$, subdomain $2(199 \times 199$ cells, $4 \times 4 \mathrm{~km})$, subdomain $3(601 \times 601$ cells, $1 \times 1 \mathrm{~km})$.

On 14 August 2015, Cotopaxi (lon. $78.436^{\circ} \mathrm{W}$, lat. $0.677^{\circ} \mathrm{S} ; 5897 \mathrm{~m}$ asl, Fig. 1) awoke after more than 70 years [9], [10]. Cotopaxi volcano is about $50 \mathrm{~km}$ south of Quito (capital of Ecuador, Fig. 1). During 2015 its eruption activity continued unevenly until the beginning of December [11]. In the same way, based on field and modeling studies, preliminary ESP were established for modeling ash dispersion at this volcano, for similar eruptions as the one happened on 14 August 2015 [12].

In this study we explore the influence of spatial resolution in modeling the dispersion of volcanic ash in Ecuador, to define a pragmatic one, for computing this information, both in forecasting time and with proper accuracy.

\section{METHOD}

We modeled the ash dispersion from four historical eruptions, three at Tungurahua (16 December 2012, 14 July 2013 and 1 February 2014) and one at Cotopaxi (14 August 2015). For these days, firstly we simulated the meteorology using the Eulerian Weather Research and Forecasting (WRF3.7.1) model [13], with a master domain of $80 \times 80$ cells (each of $36 \times 36 \mathrm{~km})$ and three nested subdomains (Fig. 1), with spatial resolutions of $12 \mathrm{~km}(109 \mathrm{x}$ 109 cells $), 4 \mathrm{~km}(199 \times 199$ cells $)$, and $1 \mathrm{~km}(601 \times 601 \mathrm{~km})$ respectively. In all cases, we used 35 vertical levels (model top pressure at $50 \mathrm{hPa}$ ). Initial and boundary conditions came from the GFS forecasts dataset [14].

Meteorological simulations were done using the following physics parameters: WSM5 for microphysics, RRTMG for radiation, Kain-Fritsch for cumulus and YSU planetary boundary 
layer (PBL) scheme. Previous studies suggested the YSU as one of the PBL schemes with good performance for modeling purposes in Ecuador [12], [15].

The meteorological outputs were used into the Eulerian FALL3DV7.1.4 [16] model to simulate the ash dispersion. Table 1 shows the ESP, emissions, timescales, and options used for modeling these four eruptions [4], [12]. We selected into FALL3DV7.1.4, the model proposed by Mastin et al. [17], to estimate the emissions of volcanic ash.

Modeled ash clouds were qualitative compared with ash clouds detected by the Washington Volcanic Ash Advisory Center (Washington VAAC) at different flight levels (FL) [18]. FL (expressed in 100 feet units) is the height above mean sea level when the pressure at sea level is $1013.2 \mathrm{mb}$ (e.g., FL300 $=30,000 \mathrm{feet}, \approx 9.1 \mathrm{~km}$ ).

We compared the modeled ash fallout results with records from ash meters around these volcanoes (4 stations for Tungurahua, 14 stations for Cotopaxi), which are operated by the Instituto Geofísico de la Escuela Politécnica Nacional [4], [11] (Fig. 2).
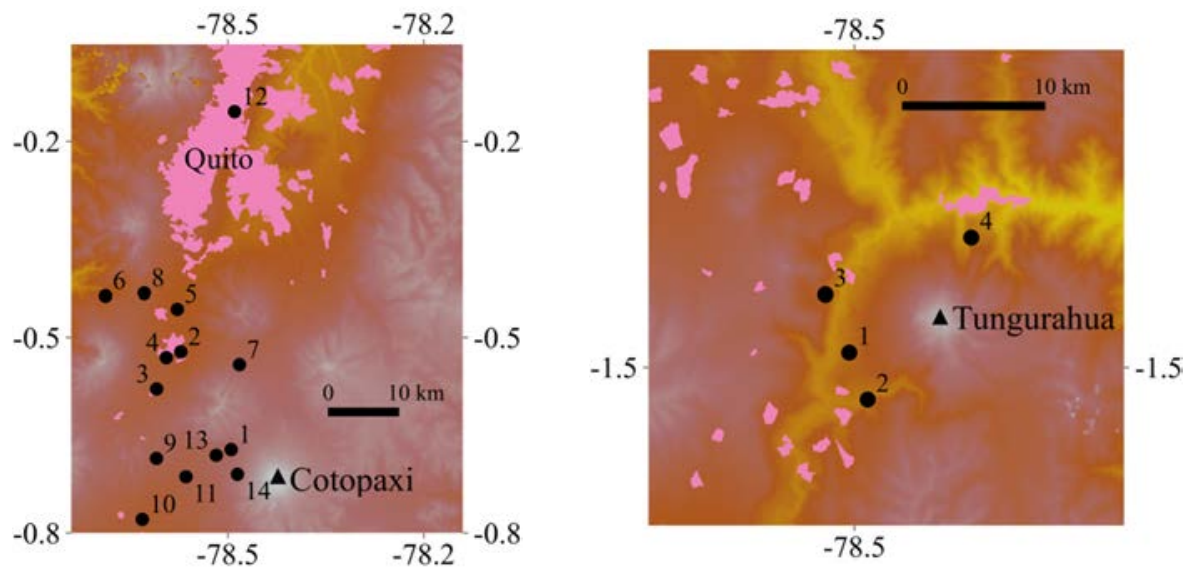

Figure 2: Location of stations and their nomenclature. Cotopaxi volcano (left): 1. Mariscal (Mar), 2. Machachi 1 (Ma1), 3. Jambelí (Jam), 4. Machachi 2 (Ma2), 5. Obelisco (Obe), 6. Aloag (Alo), 7. Santa Ana (San), 8. Gualilagua (Gua), 9. Tiopullo (Tio), 10. Progreso (Pro), 11. Entrada Sur (Ent), 12. Instituto Geofísico (Ins), 13. Agualongo (Agu), 14. BNAS. Tungurahua volcano (right): 1. Choglontus (Cho), 2. Palictahua (Pal), 3. Pillate (Pil), 4. Runtun (Run).

\section{RESULTS}

Although with differences, for all the spatial resolutions, the direction of modeled ash clouds was consistent with the course of the detected clouds. As an example, Figs 3 and 4 show the detected the corresponding computed ash clouds, for the eruptions at Tungurahua on 1 February 2014 and Cotopaxi on 14 August 2015 respectively.

For the Tungurahua eruption on 1 February 2014, at 23h15 LT (Local time), the detected clouds at FL250, FL400, and FL350 moved SE, S, and SW respectively, while the modeled moved S and SW.

For the Cotopaxi eruption on 14 August 2015, at 18h15 LT, the detected ash clouds at FL460-FL500 and FL360 moved E and N respectively, although the modeled at FL350, FL400, and FL450 moved NE. Also, modeling showed an ash cloud was moving NW at FL200, which was not detected by the Washington VAAC. 


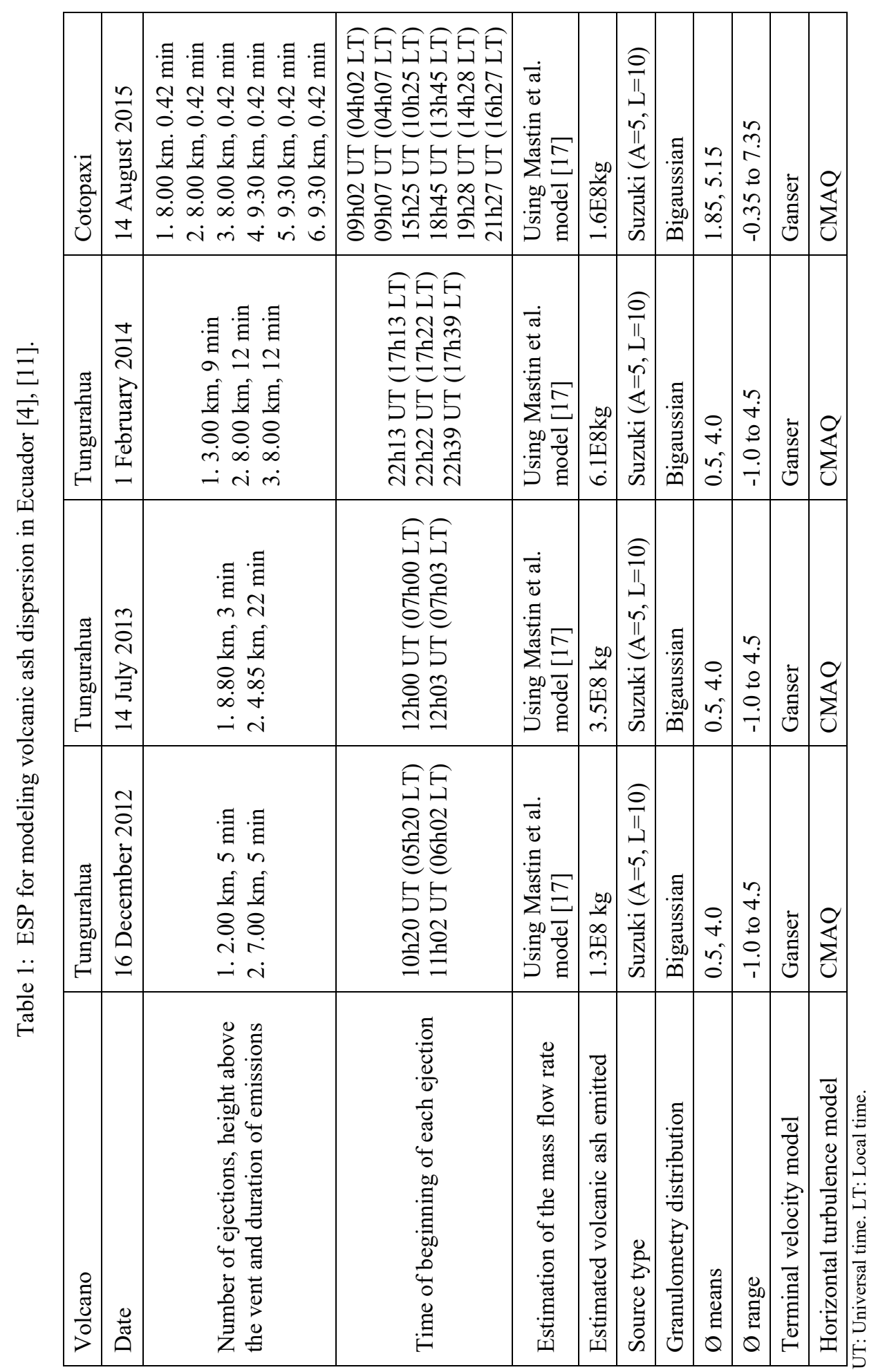




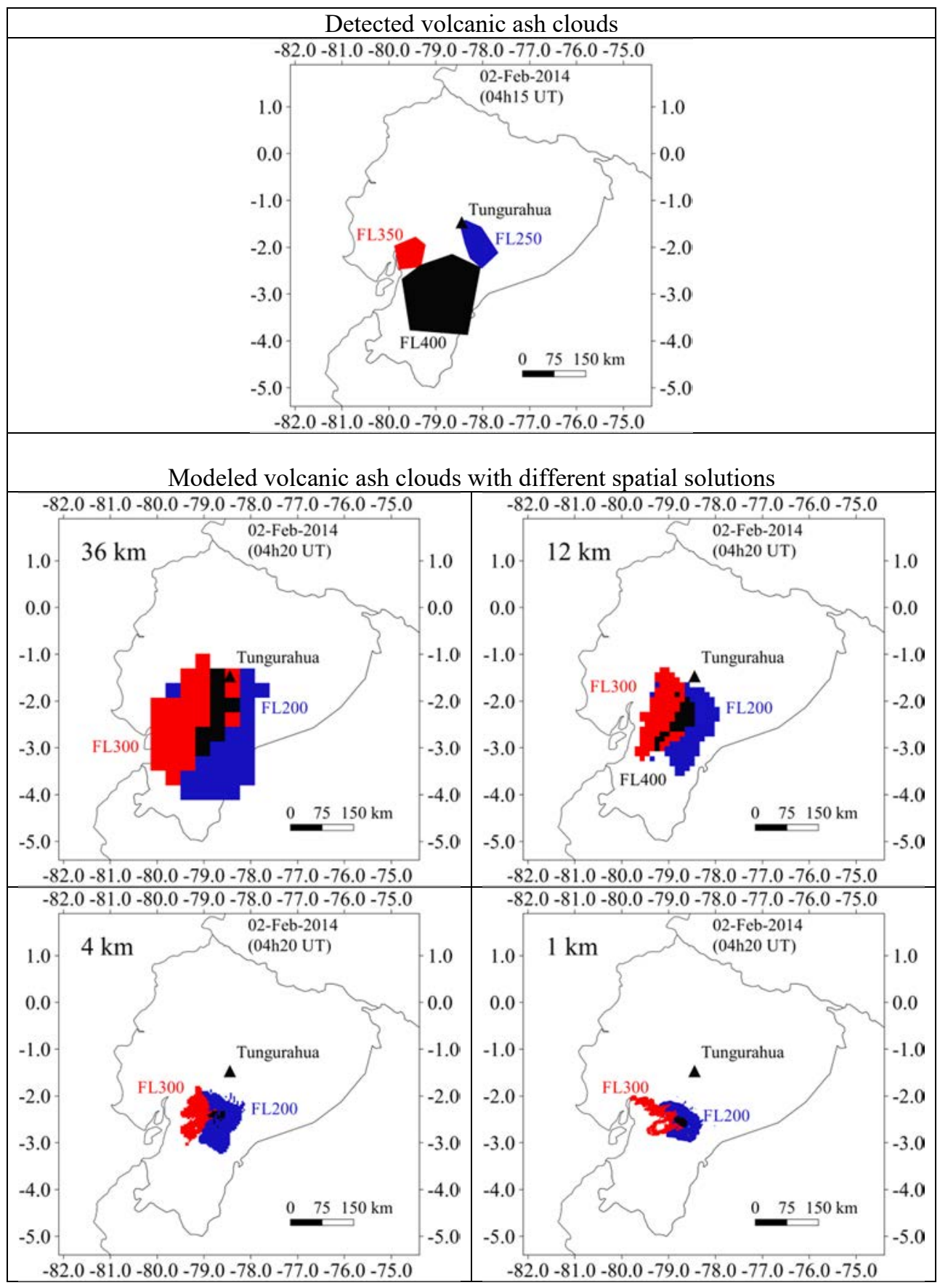

Figure 3: Tungurahua volcano. Eruption on 1 February 2014. Detected [18] versus modeled volcanic ash clouds with different spatial resolutions. 


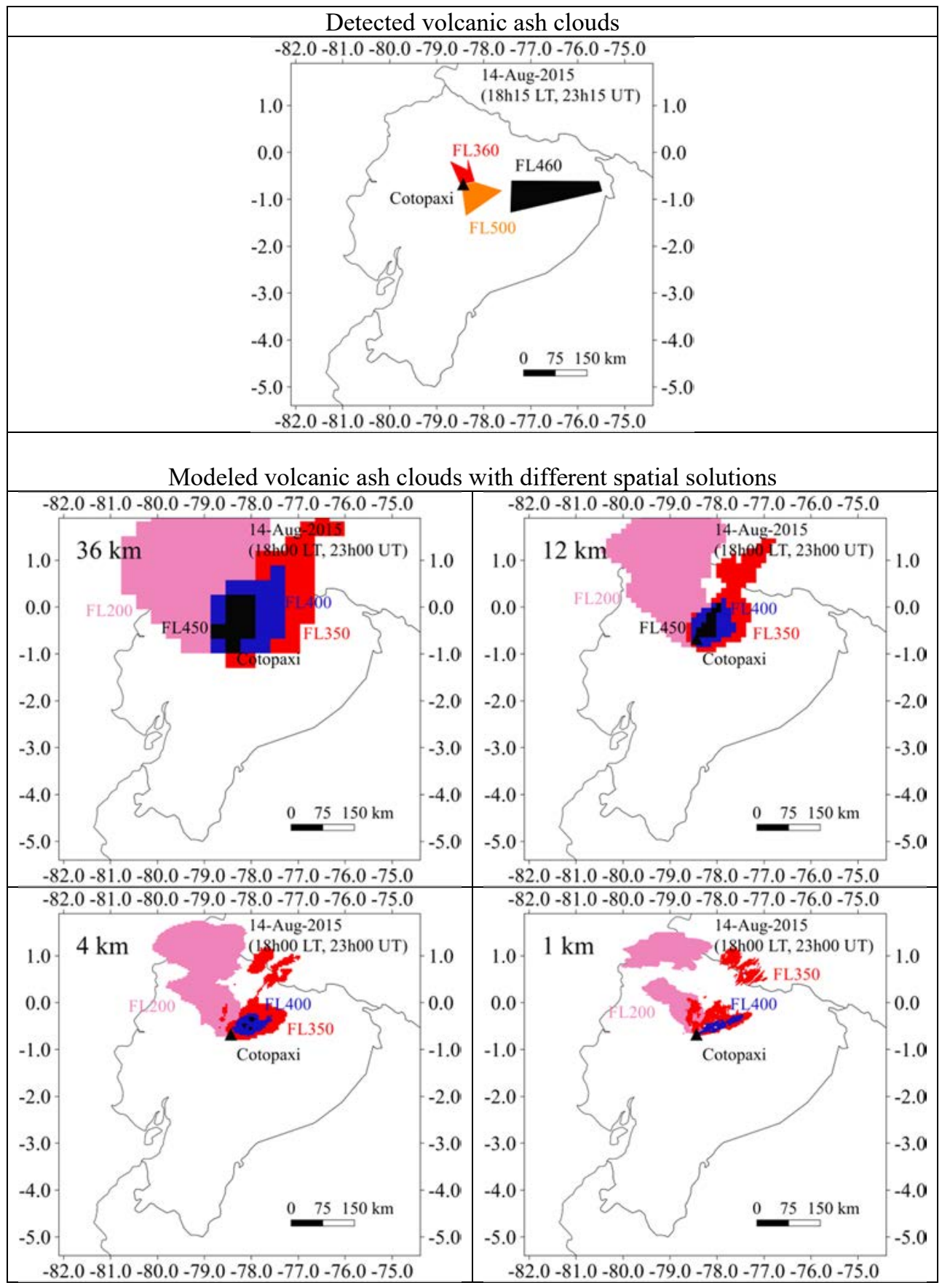

Figure 4: Cotopaxi volcano. Eruption on 14 August 2015. Detected [18] versus modeled volcanic ash clouds with different spatial resolutions. 
For all the eruptions, the simulations with coarser resolutions (36 km and $12 \mathrm{~km}$ ) provided larger areas affected by ash clouds, in comparison with the results when using higher resolutions (4 km and $1 \mathrm{~km})$.

The modeled ash fallout of 16 December 2012, 14 July 2013, and 1 February 2014, affected zones at the N, W, and SW of the crater, respectively (Figs 5-7). The ash fallout of 14 August 2015 took place mainly toward NW (Fig. 8).

When modeling with different spatial resolutions, the main computed direction of ash fallouts was the same. However, the simulations with coarser resolutions (36 km and $12 \mathrm{~km})$, provided larger areas affected by ash fallout in comparison with higher resolutions $(4 \mathrm{~km}$ and $1 \mathrm{~km}$ ). Also, coarser resolutions computed areas with ash fallout (red ellipses in Figs 5-8) which were not affected, when modeling with higher resolutions. On the other hand, higher resolutions can identify new affected zones (blue ellipses in Figs 6 and 7) in comparison with coarser resolutions, as show the results of 14 July 2013 and 14 August 2015 eruptions.

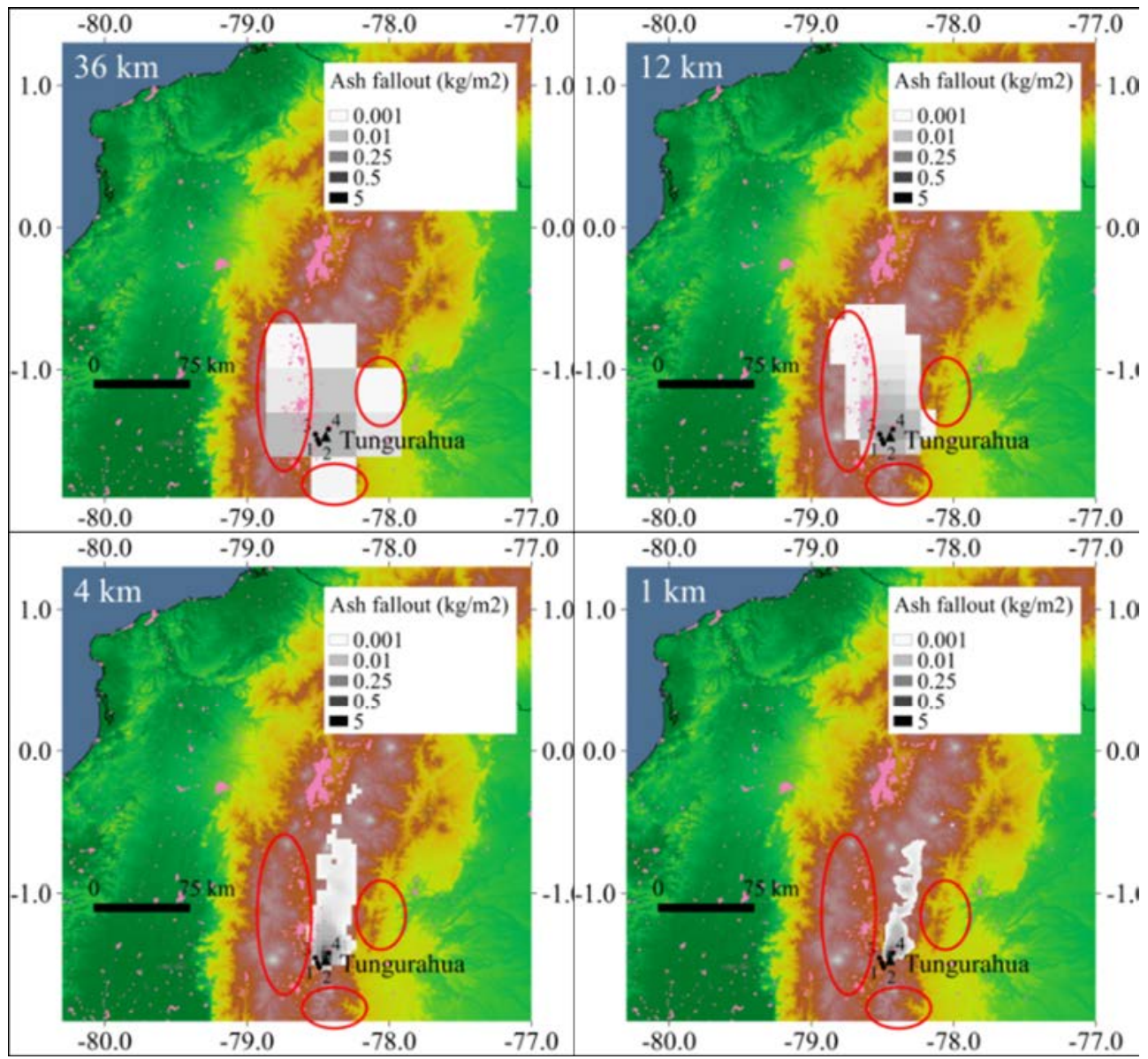

Figure 5: Tungurahua 16 December 2012. Modeled ash fallout using different spatial resolutions. 


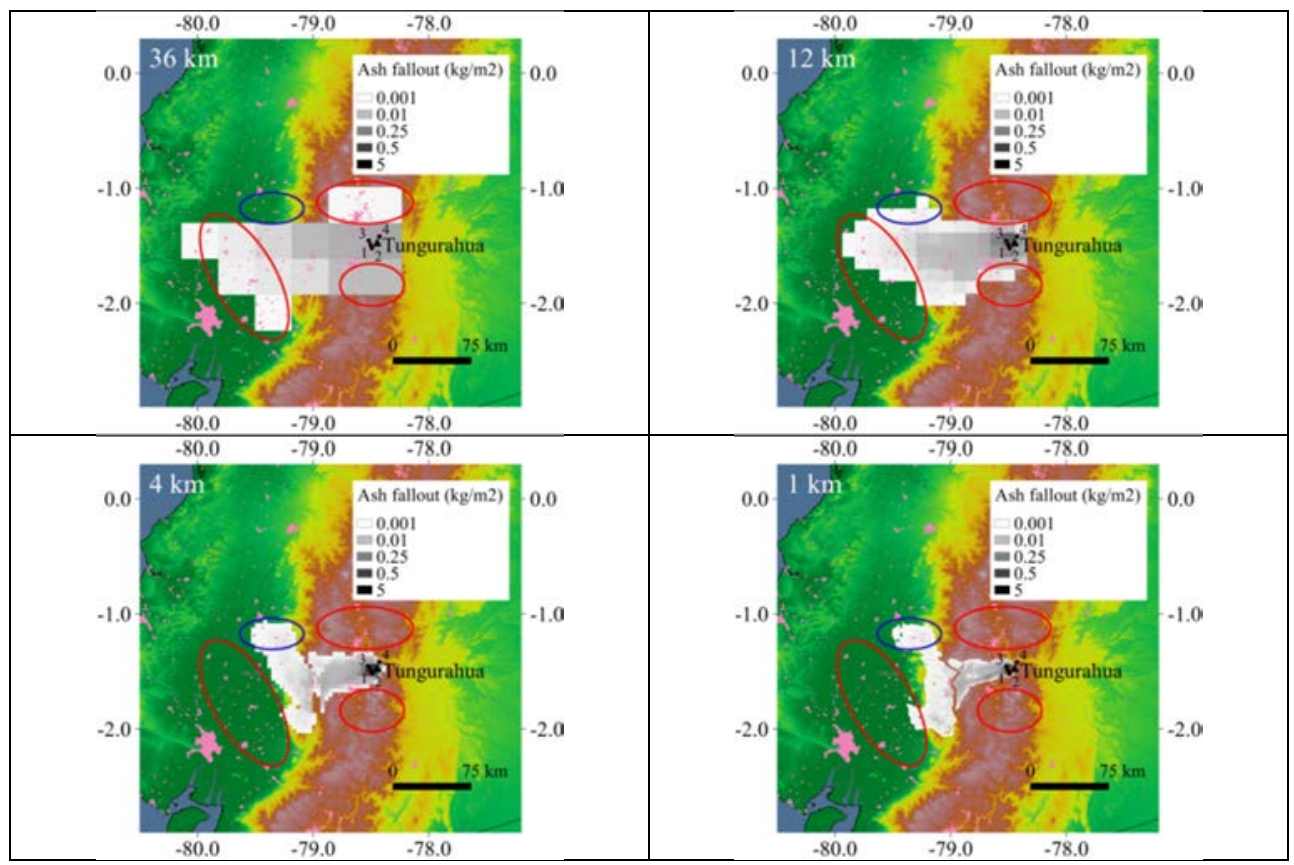

Figure 6: Tungurahua 14 July 2013. Modeled ash fallout using different spatial resolutions.

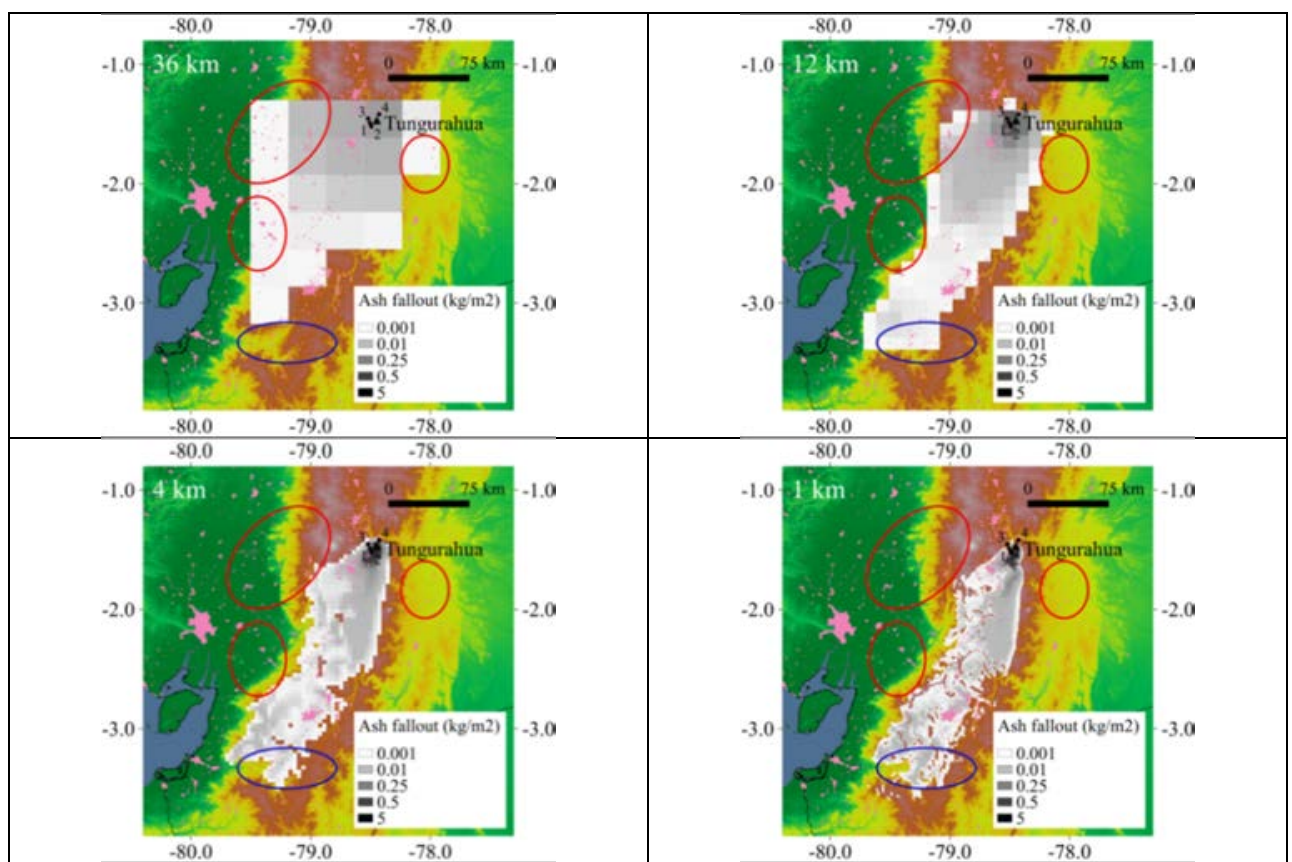

Figure 7: Tungurahua 1 February 2014. Modeled ash fallout using different spatial resolutions. 


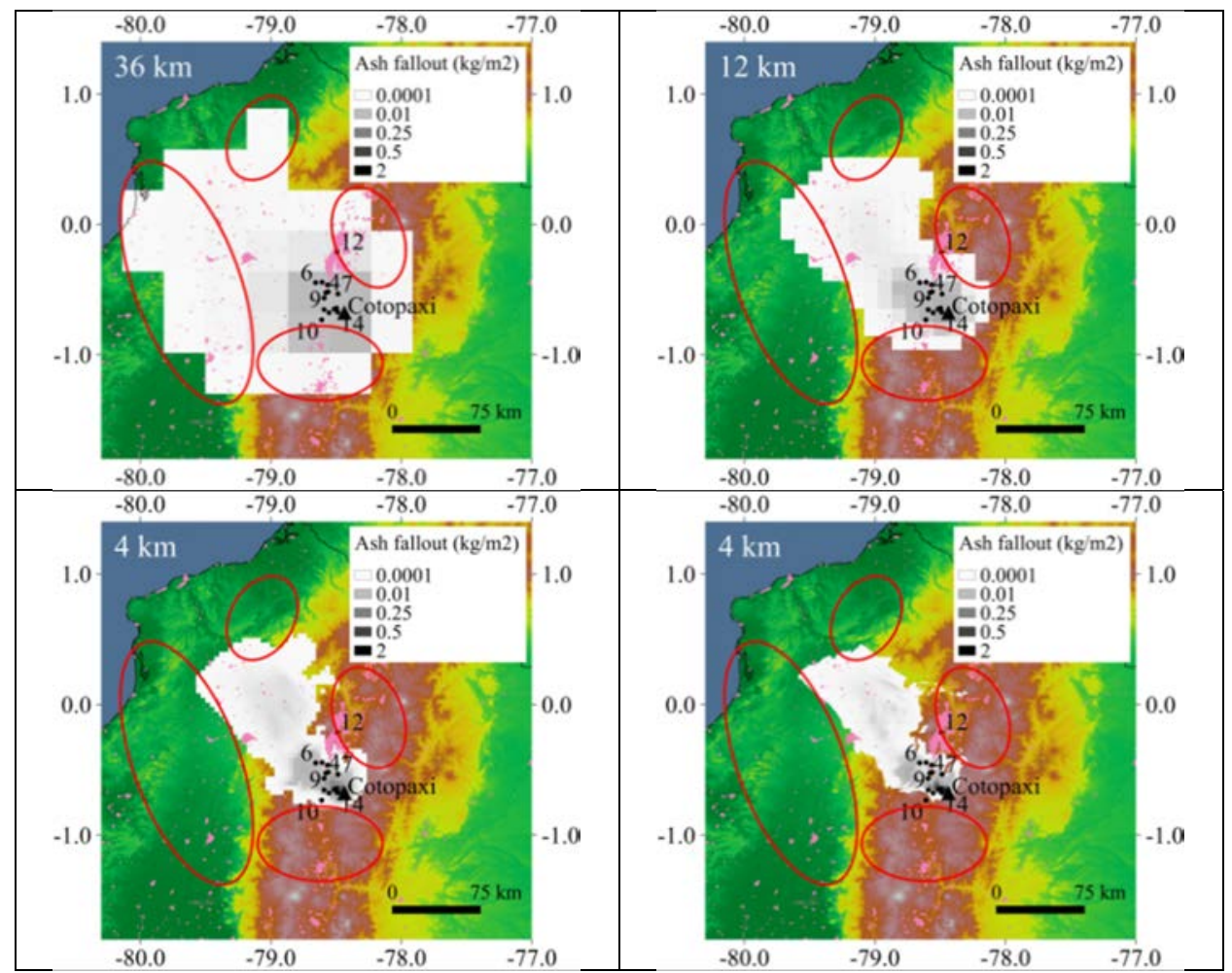

Figure 8: Cotopaxi 14 August 2015. Modeled ash fallout using different spatial resolutions.

The linear correlation coefficient $\left(\mathrm{R}^{2}\right)$ between measured and modeled ash fallout improved when using higher spatial resolutions. The coarser resolutions (36 km and $12 \mathrm{~km})$, provided low performances, with values of $\mathrm{R}^{2}$ between 0.00 to 0.79 (Table 2); and 0.28 to 0.46 respectively. The resolution of $4 \mathrm{~km}$ improved, with values of $\mathrm{R}^{2}$ between 0.56 to 0.98 . Modeling with $1 \mathrm{~km}$ got the best performance, with $\mathrm{R}^{2}$ between 0.70 to 1.00 .

As an example, Fig. 9 shows the comparison between measured and modeled ash fallout for the eruption of Cotopaxi on 14 August 2015.

Table 2: Values of the linear correlation coefficient $\left(\mathrm{R}^{2}\right)$ between measured and modeled ash fallout values using different spatial resolutions.

\begin{tabular}{|l|c|c|c|c|c|}
\hline \multirow{2}{*}{ Volcano } & \multirow{2}{*}{ Date of eruption } & \multicolumn{4}{|c|}{ Spatial resolution } \\
\cline { 3 - 6 } & & $36 \mathrm{~km}$ & $12 \mathrm{~km}$ & $4 \mathrm{~km}$ & $1 \mathrm{~km}$ \\
\hline Tungurahua & 16 December 2012 & 0.79 & 0.46 & 0.98 & 1.00 \\
\hline Tungurahua & 14 July 2013 & 0.00 & 0.28 & 0.65 & 0.95 \\
\hline Tungurahua & 1 February 2014 & 0.25 & 0.33 & 0.95 & 1.00 \\
\hline Cotopaxi & 14 August 2015 & 0.27 & 0.33 & 0.56 & 0.70 \\
\hline
\end{tabular}




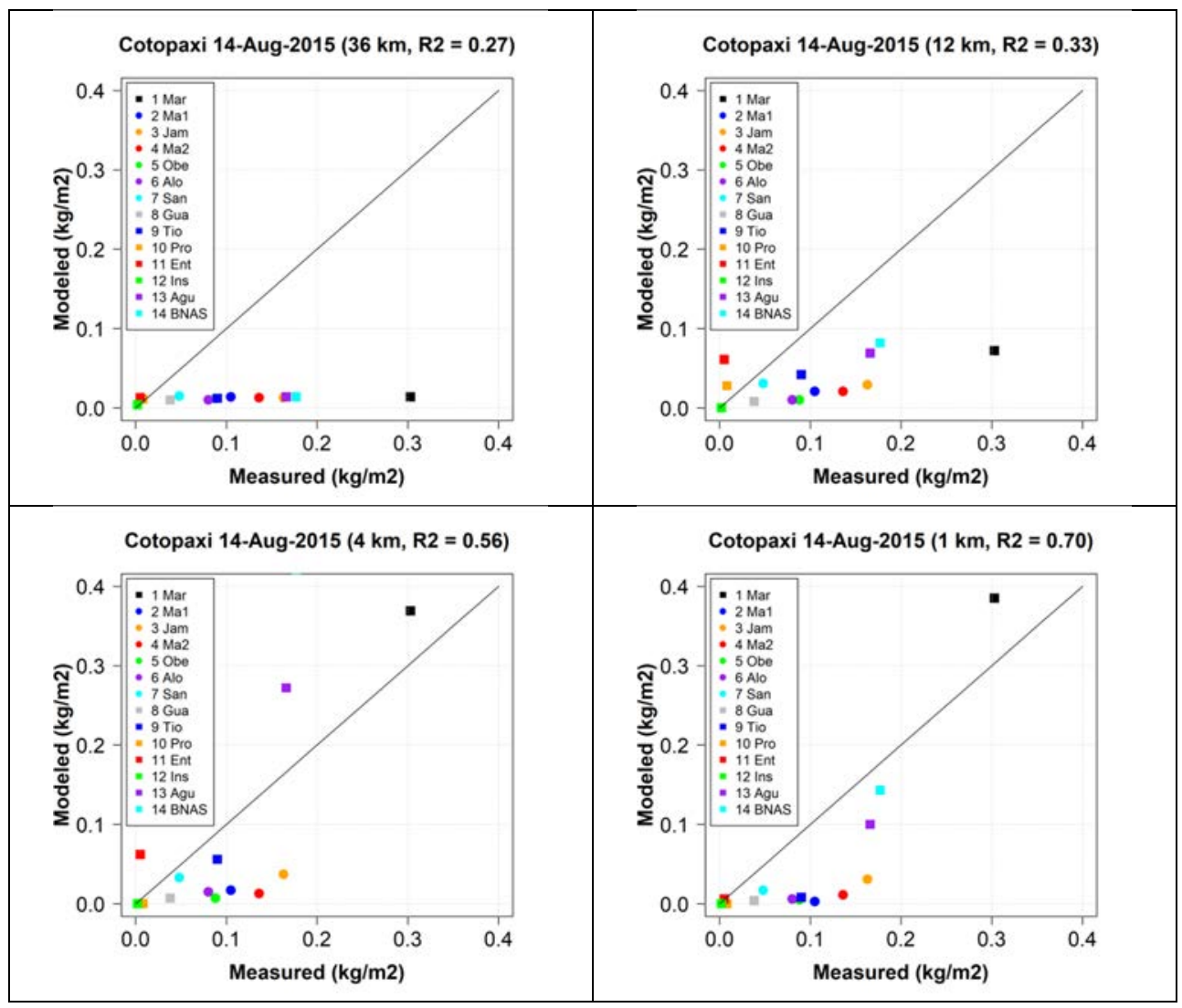

Figure 9: Cotopaxi volcano 14 August 2015. Values of the linear correlation coefficient $\left(\mathrm{R}^{2}\right)$ between measured and modeled ash fallout values using different spatial resolutions.

\section{DISCUSSION AND CONCLUSIONS}

We used spatial resolutions of $36 \mathrm{~km}, 12 \mathrm{~km}, 4 \mathrm{~km}$ and $1 \mathrm{~km}$, for modeling the dispersion of volcanic ash of four eruptions, which took place in Ecuador in the last seven years.

Although with differences in shape and height, the direction of the modeled ash clouds with these resolutions, were consistent with the course of the detected ash clouds. For all the eruptions, the coarser simulations $(36 \mathrm{~km}$ and $12 \mathrm{~km})$ provided larger areas affected by ash clouds, in comparison with the results when modeling with higher resolutions $(4 \mathrm{~km}$ and $1 \mathrm{~km})$. The coarser simulations also provided larger areas affected by ash fallout, in contrast with the results when using higher resolutions.

For all the eruptions, the linear correlation coefficient $\left(\mathrm{R}^{2}\right)$ between measured and modeled ash fallout improved when using higher resolutions. The simulations using $4 \mathrm{~km}$ and $1 \mathrm{~km}$ reached values of $\mathrm{R}^{2}$ between 0.56 to 0.98 , and 0.70 to 1.00 respectively.

Nowadays and based on the WRF3.7.1 and FALL3D7.1.4 models [19], we are using a numerical system for forecasting the potential path of volcanic ash, due to emissions at Tungurahua and Cotopaxi volcanoes. This system is working with $4 \mathrm{~km}$ of spatial resolution, under the following schedule: During the first day, WRF generates the meteorology for the 
next four days. After, FALL3D models the volcanic ash dispersion for the second, third and fourth days. Now, the computational resources dedicated to this task (24 processors, E5, 2.00 $\mathrm{GHz}$ and $65.9 \mathrm{~GB}$ of RAM [19]) require about $24 \mathrm{~h}$ for processing this schedule.

Using the same resources but working with the spatial resolution of $1 \mathrm{~km}$, the computational time increased to about 20 days. So, with this resolution, although with better performance, the computed information will not be available in forecasting time.

These results suggest that for the Ecuadorian case, with the actual computational resources, the resolution of $4 \mathrm{~km}$ is a good compromise, which allows the generation of volcanic ash dispersion in forecasting time, with proper modeling performance.

This framework uses an off-line approach. It firstly forecasts the meteorology and after the volcanic ash dispersion.

The advantage of this approach is that a unique database provides the meteorological data for forecasting ash dispersion at different volcanoes. This feature is significant, especially in cases of limited computational resources. Once the meteorology is available, it is possible to forecast in almost real time, the dispersion of volcanic ash, if the beginning time of an actual eruption is known.

Nevertheless, the off-line approach does not consider feedback between volcanic ash and meteorology. The online modeling approach, which works with interactions, could improve the performance. The disadvantage of the online method is the need for larger computational capacities, in part because the ash dispersion of a single eruption demands its meteorology.

\section{ACKNOWLEDGEMENTS}

This research is part of the project "Sistema de pronóstico de dispersión de ceniza volcánica en el Ecuador: septiembre 2018-agosto 2019" funded with the USFQ Poli-Grants 20182019. Simulations were done at the High Performance Computing system at the USFQ.

\section{REFERENCES}

[1] Ayris, P.M. \& Delmelle, P., The immediate environmental effects of tephra emission. Bulletin of Volcanology, 74, pp. 1905-1936, 2012. DOI: 10.1007/s00445-012-0654-5.

[2] Horwell, C.J. \& Baxter P.J., The respiratory health hazards of volcanic ash: a review for volcanic risk mitigation. Bulletin of Volcanology, 69(1), pp. 1-24, 2006.

[3] Folch, A., Jorba, O. \& Viramonte, J., Volcanic ash forecast: Application to the May 2008 Chaitén eruption. Natural Hazards and Earth System Sciences, 8, pp. 927-940, 2008. DOI: 10.5194/nhess-8-927-2008.

[4] Parra, R., Bernard, B., Narváez, D., Le Pennec, J.-L., Hasselle, N. \& Folch, A., Eruption source parameters for forecasting ash dispersion and deposition from vulcanian eruptions at Tungurahua volcano: Insights from field data from the July 2013 eruption. Journal of Volcanology and Geothermal Research, 309, pp. 1-13, 2016. DOI: 10.1016/j.jvolgeores.2015.11.001.

[5] Bonadonna, C., Folch, A., Loughlin, S. \& Puempel, H., Future developments in modelling and monitoring of volcanic ash clouds: outcomes from the first IAVCEIWMO workshop on Ash Dispersal Forecast and Civil Aviation. Bulletin of Volcanology, 74, pp. 1-10, 2012. DOI: 10.1007/s00445-011-0508-6.

[6] Falasca, S. \& Curci, G., High-resolution air quality modeling: Sensitivity tests to horizontal resolution and urban canopy with WRF-CHIMERE. Atmospheric Environment, 187, pp. 241-254, 2018. DOI: 10.1016/j.atmosenv.2018.05.048.

[7] Le Pennec, J.-L., Ruiz, G.A., Ramón, P., Palacios, E., Mothes, P. \& Yepes, H., Impact of tephra falls on the Andean communities: The influences of eruption size and weather 
conditions during the 1999-2001 activity of Tungurahua volcano. Ecuador. Journal of Volcanology and Geothermal Research, 217-218, pp. 91-103, 2012.

DOI: 10.1016/j.jvolgeores. 2011.06.011.

[8] Bernard, B., Bustillos, J., Wade, B. \& Hidalgo, S., Influence of the wind direction variability on the quantification of tephra fallouts: December 2012 and March 2013 Tungurahua eruptions. Avances en Ciencias e Ingenierías, 5-1, pp. A14-A21, 2013.

[9] Hidalgo, S. et al., Cotopaxi volcano's unrest and eruptive activity in 2015: Mild awakening after 73 years of quiescence. Abstract Volume of the 2016 EGU General Assembly, p. EGU2016-5043-1, 2016.

[10] Gaunt, H.E. et al., Juvenile magma recognition and eruptive dynamics inferred from the analysis of ash time series: The 2015 reawakening of Cotopaxi volcano. Journal of Volcanology and Geothermal Research, 328, pp. 134-146, 2016.

[11] Bernard, B. et al., Relationship between volcanic ash fallouts and seismic tremor: Quantitative assessment of the 2015 eruptive period at Cotopaxi volcano, Ecuador. Bulletin of Volcanology, 78, 80, 2016. DOI:10.1007/s00445-016-1077-5.

[12] Parra, R., Influence of boundary layer schemes in modeling the dispersion and sedimentation of volcanic ash in Ecuador. Wit Transactions on Ecology and the Environment, vol. 230, WIT Press: Southampton and Boston, pp. 83-94, 2018. DOI: $102495 / A I R 180081$.

[13] Weather Research and Forecasting Model, http://wrf-model.org. Accessed on: 10 Dec. 2018.

[14] Global Forecast System (GFS), www.ncdc.noaa.gov/data-access/model-data/modeldatasets/global-forcast-system-gfs. Accessed on: 10 Dec. 2018.

[15] Parra, R., Performance studies of planetary boundary layer schemes in WRF-chem for the Andean Region of southern Ecuador. Atmospheric Pollution Research, 9, pp. 411428, 2018. DOI: 10.1016/j.apr.2017.11.011.

[16] Folch, A., Costa, A. \& Macedonio, G., FALL3D: A computational model for transport and deposition of volcanic ash. Computers and Geosciences, 35(6), pp. 1334-1342, 2009.

[17] Mastin, L.G. et al., A multidisciplinary effort to assign realistic source parameters to models of volcanic ash-cloud transport and dispersion during eruptions. Journal of Volcanology and Geothermal Research, 186, pp. 10-21, 2009.

[18] Washington VAAC, www.ssd.noaa.gov/VAAC/messages.html. Accessed on: 10 Dec. 2018.

[19] Parra, R., Numerical system for forecasting volcanic ash dispersion in Ecuador. IEEE Third Ecuador Chapter Meeting (ETCM), pp. 1-5, 2018.

DOI: 10.1109/ETCM.2018.8580331. 